\title{
CORRIGENDUM
}

\section{POLITIC, CAUTIOUS, AND METICULOUS: AN INTRODUCTION TO THE SYMPOSIUM ON THE MARSHALL ISLANDS CASE-CORRIGENDUM}

\author{
Antony T. Anghie
}

doi: 10.1017/aju.2017.27, Published by Cambridge University Press, 30 May 2017.

Due to an editing error, we regret that the dates relating to Hiroshima (August 6, 1945) and Nagasaki (August 9, 1945) were inadvertently reversed in the original version of this essay. ${ }^{1}$

1 Antony T. Anghie, Politic, Cautious, and Meticulous: An Introduction to the Symposium on the Marshall Islands Case, 111 AJIL UNBOUND 62,65 (2017).

The American Society of International Law and Antony T. Anghie (C 2017. This is an Open Access article, distributed under the terms 